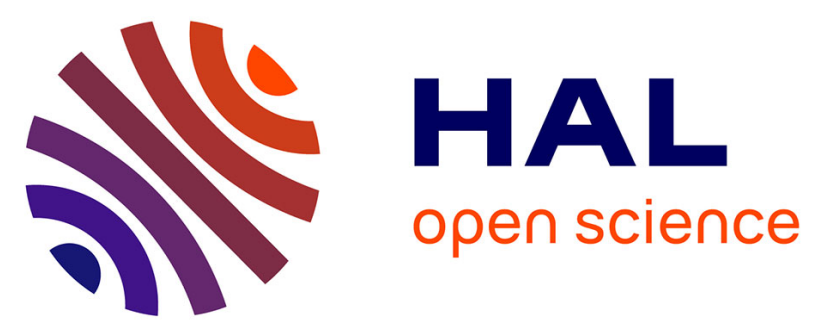

\title{
Cussac Cave (Dordogne, France): The role of the rock support in the parietal art distribution, technical choices, and intentional and unintentional marks on the cave walls
}

Catherine Ferrier, Stephane Konik, Marie Ballade, Camille Bourdier, Rémy

Chapoulie, Valérie Feruglio, Alain Queffelec, Jacques Jaubert

\section{To cite this version:}

Catherine Ferrier, Stephane Konik, Marie Ballade, Camille Bourdier, Rémy Chapoulie, et al.. Cussac Cave (Dordogne, France): The role of the rock support in the parietal art distribution, technical choices, and intentional and unintentional marks on the cave walls. Quaternary International, 2017, 430, pp.30-41. 10.1016/j.quaint.2016.04.002 . hal-02140140

\author{
HAL Id: hal-02140140 \\ https://hal.science/hal-02140140
}

Submitted on 22 Jun 2020

HAL is a multi-disciplinary open access archive for the deposit and dissemination of scientific research documents, whether they are published or not. The documents may come from teaching and research institutions in France or abroad, or from public or private research centers.
L'archive ouverte pluridisciplinaire HAL, est destinée au dépôt et à la diffusion de documents scientifiques de niveau recherche, publiés ou non, émanant des établissements d'enseignement et de recherche français ou étrangers, des laboratoires publics ou privés. 


\title{
Cussac Cave (Dordogne, France): The role of the rock support in the parietal art distribution, technical choices, and intentional and unintentional marks on the cave walls
}

Catherine Ferrier ${ }^{\mathrm{a}}$, Stéphane Konikb, Marie Ballade ${ }^{\mathrm{a}}$, Camille Bourdier ${ }^{\mathrm{c}}$, Rémy Chapoulie ${ }^{\mathrm{d}}$, Valérie Feruglio ${ }^{\mathrm{a}}$, Alain Queffelec ${ }^{\text {a }}$, Jacques Jaubert ${ }^{\mathrm{a}}$

\author{
a Université de Bordeaux - PACEA, UMR 5199 CNRS-UB-MCC, Allée Geoffroy Saint Hilaire, CS 50023, F-33615 Pessac Cedex, \\ France \\ ${ }^{\mathrm{b}}$ Ministère de la Culture et de la Communication - Centre national de Préhistoire, Université de Bordeaux - PACEA, 38 rue du 26e \\ Régiment d'Infanterie, F-24000 Périgueux, France \\ ${ }^{\mathrm{c}}$ Université de Toulouse Jean Jaurès, TRACES, UMR 5608 CNRS-UTJJ - MCC, Maison de la Recherche, 5 allées Antonio Machado, F- \\ 31058 Toulouse, France \\ d Université Bordeaux Montaigne - IRAMAT-CRP2A, UMR 5060 CNRS-UBM - Maison de l'Archéologie, F-33607 Pessac Cedex, \\ France
}

\section{Abstract}

In this article, we present the relationships observed between the properties of the rock support in Cussac Cave and the choices made by the Paleolithic artists: the lithology of the limestone and the speleogenesis of the cave resulted in the creation of the vast rock surfaces on which the artists realized monumental engravings. The cartography of the formation processes in the cave and the petrographic analysis of samples collected from the ground show that following a superficial dissolution of the limestone, the rock became softer, thus facilitating engraving, even with a soft tool. The analyses (X-ray Diffraction, X-ray Fluorescence, Raman Spectrometry) indicate a relative concentration of goethite, responsible for the orangish patina visible on the wall surfaces. When engraved, the lighter material under this patina is exposed in the bottom of the incised lines, creating contrasting colors that contribute to the visibility of the depictions. Finally, the alteration of the limestone created a surface that also facilitated the realization of more tenuous marks, such as finger-tracings, as well as involuntary marks made by resting hands

Keywords: Geoarchaeology ; Taphonomy ; Parietal art ; Engraving ; Gravettian

\section{Introduction}

In the early 20th century, researchers began to recognize the phenomena responsible for wall surface alterations in decorated caves, largely thanks to the work of Henri Breuil in Font de Gaume Cave, Dordogne (Capitan et al., 1910). Later, in Pech-Merle (Lot), Amed ee Lemozi was also interested in the morphology of the rock support and its relationship to the parietal art works (Lemozi, 1929). But Michel Lorblanchet would be the first to consider the karstic environment and its evolution as fundamental to understanding parietal art, believing that their study was a necessary first step that could provide insights on the distribution of the depictions and the unfinished nature of some of them (Lorblanchet et al., 1973). Lorblanchet (1993, p.70) also considered the support and its alterations to be a determining factor in the technical choices of the artists (he observed this in his work in Australia as well). For him "the techniques used to realize the parietal depictions were adapted to the alterations of the support. The most perfect example of such an adaptation is the finger-tracing technique, which we find in decorated caves containing both Paleolithic decorations and easily accessible surfaces covered with mondmilch (in 17 decorated caves in Europe) (Lorblanchet, 1992)". Philippe Renault, enlisted by Lorblanchet to study the karstology and micromorphology of cave walls, defined the fundamental questions and interpretive reasoning on this subject (Renault, 1987, 1989), which he applied in his study of the caves of Sainte-Eulalie at Espagnac, PechMerle both in Quercy (Lorblanchet et al., 1973, 1979), and Niaux, Pyrenees. More recently, in Lascaux Cave, monitoring of the walls through stereo-photography, macrophotography and cartography revealed the complexity 
of the calcite alteration processes in some of the decorated sectors (Brunet andVouve,1996 ). Finally, we cannot recount the history of this research without mentioning the work of Norbert Aujoulat, especially in Lascaux Cave, who believed that parietal art must be studied through a global approach including the geomorphological context and its evolution (Aujoulat, 2004). This research approach has been developed most recently and most completely in the study of Chauvet-Pont d'Arc Cave, where analyses of the evolution of the support characteristics sheds light on the artists' choices of decorated sectors and artistic techniques, as well as on the taphonomic processes that have modified the parietal depictions (Kervazo et al., 2010; Ferrier et al., 2012).

From the beginning of the archaeological study of Cussac Cave (Dordogne), we have also considered that the relationships between the parietal art works and their rock supports is fundamental; this particularly significant in Cussac Cave since the it is formed within limestone beds with petrographic features and contrasting surface characteristics that offered supports with varying properties to the Paleolithic artists. Our study is therefore based on an interdisciplinary approach involving parietal art specialists, geoarchaeologists and archaeometric specialists. In this article, we present the questions raised by the interactions between the rock supports and the parietal art in Cussac Cave, our methodology, and the advances made based on a confrontation of the first results obtained.

\section{Cussac Cave}

\subsection{Location and geological context}

Cussac Cave is located in the southern Perigord region in France, near the town of Le Buisson-de-Cadouin (Fig. 1). It opens at $118 \mathrm{~m}$ altitude on the right bank of the Belingou, a tributary stream of the Dordogne River. It is formed within Upper Campanian limestones in the Couze formation (Karnay et al., 1999) composed of variably sandy limestones deposited in an open platform characteristic of a proximal facies (Platel, 1989, 1996).

The cavity is composed of a single, meandering, sub-horizontal gallery at least $1.6 \mathrm{~km}$ long that splits into two branches starting fromthe location of the current entrance. The tunnel is $10-15 \mathrm{~m}$ wide and an average of 12 m high (Aujoulat et al., 2001a and b, 2002). 

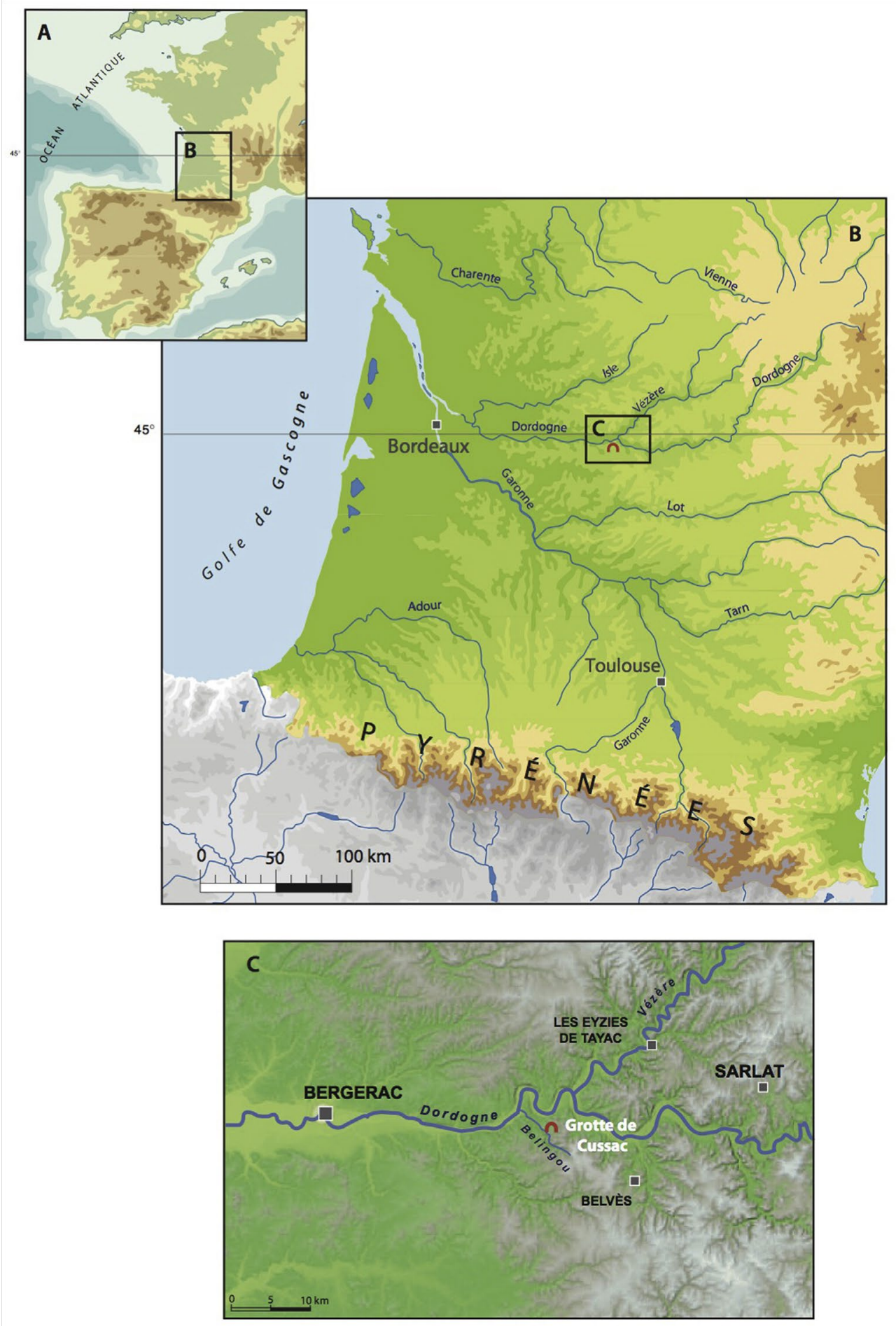

Fig. 1. Location of Cussac cave.

\subsection{Archaeological context}

The cave was discovered in September 2000 during a survey by Marc Delluc and members of the SpeleoClub de Perigueux (Delluc, 2000). It is both a decorated and sepulchral cave (Aujoulat et al., 2000; HenryGambier et al., 2013). The parietal art consists almost entirely of engravings that are most often grouped together on panels. In addition to numerous motifs, the engravings depict, in descending order, bison, mammoths, horses and aurochs (Aujoulat et al., 2013). Other species, goose, ibex, rhinoceros, bear and feline, are less numerous. Female silhouettes and male and female sexual genitalia are also represented. 
The Gravettian attribution of the art in Cussac Cave is based on comparisons with other caves. It themes and associations, such as female and mammoth figures, recall those at Pech-Merle, while it shares formal conventions with Gargas and Roucadour, and compositional ones with Pech-Merle (Aujoulat et al., 2001a, 2001b, 2002, 2004 and 2005).

Human remains have been found in three sectors (Loci 1, 2 and 3). They are associated with, and sometimes deposited inside, bear hibernation hollows (Henry-Gambier et al., 2013). A human bone in Locus 1 has yielded a ${ }^{14} \mathrm{C}$ date contemporary with the Gravettian period $(25,120 \pm 120$ BP Beta 156643 or 29,500-28,835 calBP, IntCal13) (Aujoulat et al., 2001a).

The cave also contains abundant evidence of animal and human presence, consisting of tracks, claw marks, polish, broken concretions and torch smears. A date obtained from a torch smear is coherent with that of the dated human bone (Jaubert et al., 2016).

\section{Aims of the study}

This study explores the links between the properties of the rock support and various aspects of the parietal art in Cussac Cave. This relationship was already discussed in the first publications of this cavity (Aujoulat et al., 2001a, 2002), in which the authors observed that most of the graphic depictions were realized on the middle segment of the wall, often on a protruding or overhanging area with a soft, fine-grained surface and no marked relief. They also noted the remarkable adaptation of the graphic techniques to the mechanical and optical properties of the wall: "the hardness of the wall permits an excellent preservation of the art, while being sufficiently soft to enable its realization with a stone, bone, or even hard wood tool. The continuous incisions are wide and deep, contrasting with the background due to both the chromatic variations created by the removal of the ochre colored calcin and the width of the line." At the beginning of the study of the cave, the softness of the wall surface was linked to a disaggregation of the limestone, resulting in small accumulations of sand at the foot of the wall or irregularities on its surface.

Proceeding from these observations, we defined the following aims for our study:

to verify the relationships between the lithology and the locations of the parietal depictions; to determine the nature of the rock surface alterations at the microscopic scale through the study of thin sections with a polarized light microscope, and to confirm the genetic link between the limestone and the sand accumulations through a petrographic analysis

to understand the reasons for the color difference between the rock surface and the engraved lines; to consider the influence of the rock surface properties on the artists' technical choices and the visual appearance of the engraved lines.

\section{Methods}

This study is part of a broader interdisciplinary program developed with the aim of understanding the age and nature of the human incursions into this decorated and sepulchral cave (Jaubert et al., 2012). As with most recently discovered or currently studied decorated caves, we must adhere to strict regulations concerning access and circulation within the cave, requiring very limited invasive operations in order to protect this original and truly exceptional site (Fourment et al., 2012; Jaubert et al., 2012; Jaubert, 2015).

\subsection{Field recording}

\subsubsection{Sand accumulations}

The sand accumulations present on the cave floor, created by the disaggregation of the walls and ceiling, were recorded on the topographic map of the cave. These recordings were made in the Downstream Branch, from the entry zone to the Grand Panel (5G2). A color gradation was used to represent the quantity of sand grains and the degree of continuity of the accumulations (Fig. 2). Symbols are used to indicate the type of rock on which the 
sand grains are deposited: limestone, calcite or clay. This recording enabled us to obtain a global perception of the variability and intensity of this phenomenon.
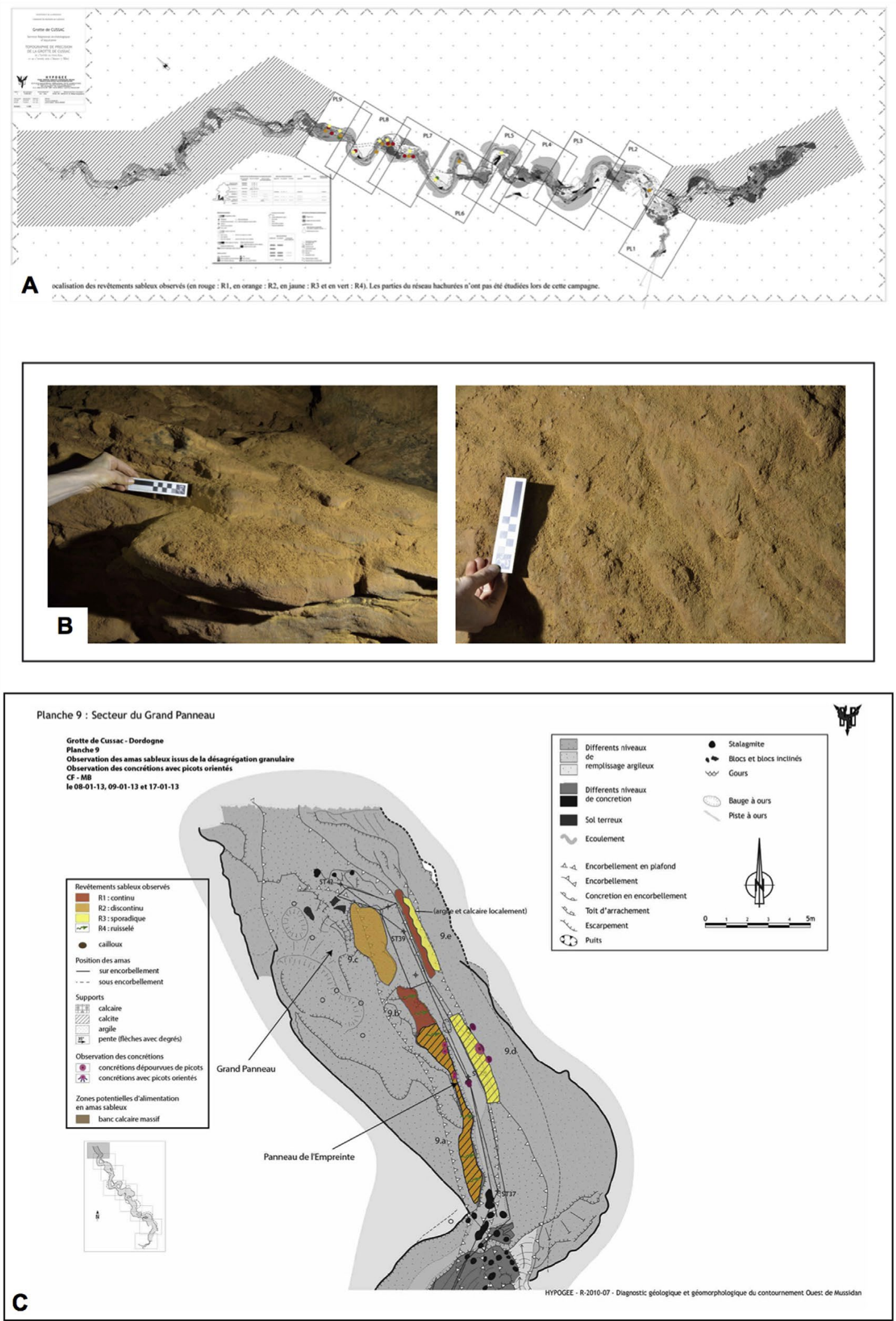

Fig. 2. Map of the sand accumulations resulting from the disaggregation of the cave walls (recording, M. Ballade, C. Ferrier, S. Konik; topographic background, Hypogee). A e Location of the sector studied (topographic background, Hypogee). B and C e continuous sand accumulations on the left, and discontinuous ones on the right (photos S. Konik, PCR Cussac). D: Example of mapped sand accumulations in the Grand Panel sector. 
The Triptych Panel (Fig. 3) is located in the Downstream Branch, after locus 3, between the Panel of the Mammoths (4D1) and the Panel of Facing Animals (4D2), approximately 250e255 m from the current entrance. It is located at eye-level, near the most accessible path and is composed of three groups of engravings: in the right group there are two "serpentine" forms composed of sinuous lines (4G1-1 and 2); in the center group, an engraved animal associates the hindquarters and neck of a bison with a horse head (4G1-4), with a sinuous line crossing the figure (4G1-3). The right group is more complex, composed of an animal head with large ears or horns turned toward the left (4G1-8), an undetermined motif (4G1-6) resembling the goose in the Upstream Branch, fingertracings (4G1-7) and deeply engraved, undetermined motifs (4G1-9 and 10).

The taphonomic recording of this panel includes:

- the support: micro-topography (ridges and concave zones, fissures, cupules, rugosity), clay infill in fissures, calcitic coating, observed by naked eye and reported on photographs.

- the anthropogenic transformations: engravings, finger-tracings, involuntary leaning and rubbing;

This recording thus represents the different states of the wall and their chronology relative to the anthropogenic lines and marks.
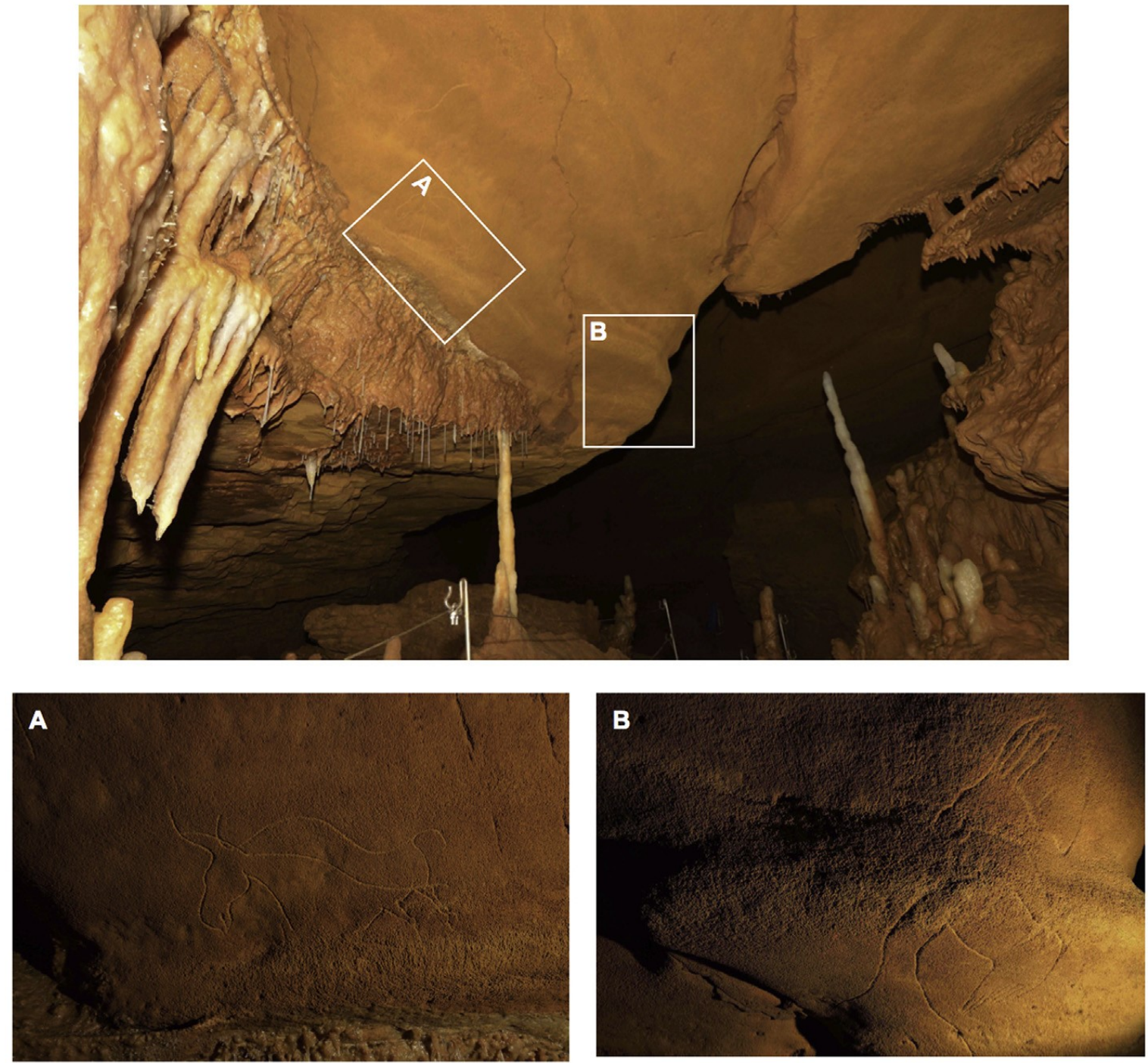

Fig. 3. Triptych Panel. The wall is delimited at the bottom by a flat surface corresponding to a stratification joint separating the thick limestone beds from the thinner ones. The engravings were realized above the joint, which is emphasized by stalactites. A: horseebison in the central group; B: an animal head and motif resembling a goose in the right group (photos S. Konik, PCR Cussac). 


\subsection{Laboratory analyses}

The regulations stipulated to preserve the site forbid any damaging removal of material from the site and thus limit the samples that can be taken. A few rock fragments that were naturally detached from the walls or ceiling and fell on the floor near the authorized path, as well as sandy, non-calcitic coverings, could therefore be collected.

Five samples were made in the laboratory (Fig. 4):

- Three limestone samples. The first one was collected from a pile of rocks created by the collapse of bedded layers on the right wall near the entrance rockfall. The two others are clasts fallen from the thick beds. One comes from the Upstream Branch and the other from the foot of the Grand Panel. These two samples, though distant from each other, are representative of the degree of alteration of the walls, visible in both sectors.

- Two sand samples collected at the foot of the walls: one under the left group of the Triptych Panel, the other opposite the Grand Panel.

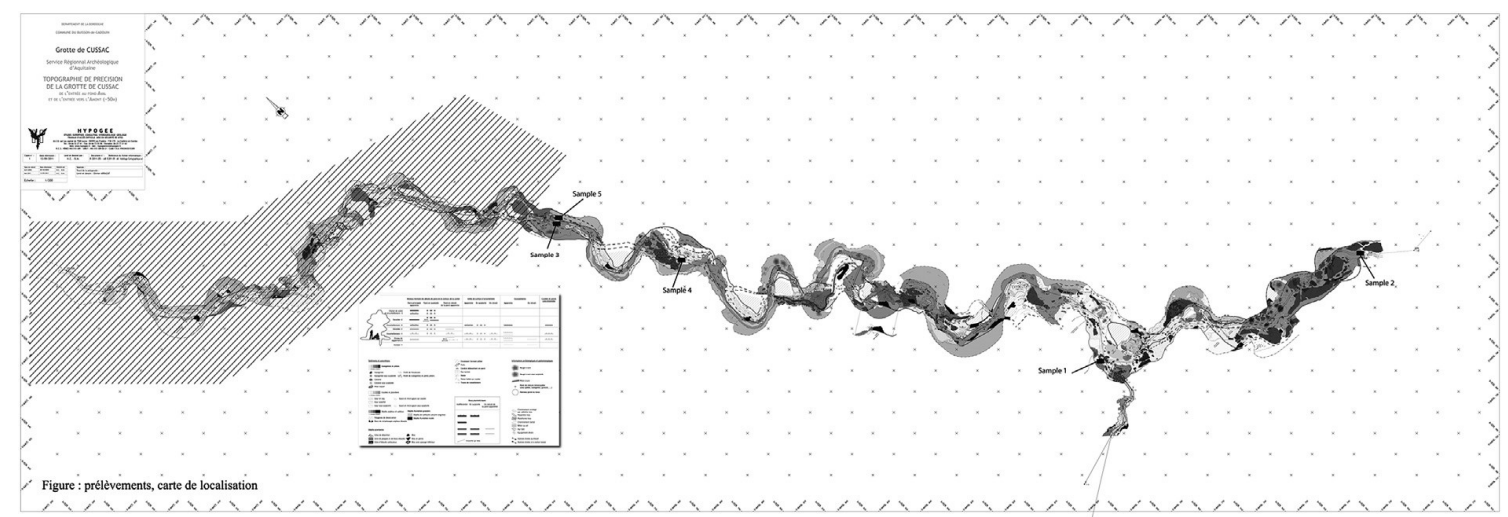

Fig. 4. Location of the samples studied. 1: limestone block collected from the bedded layer rockfall. 2: clast fallen from a thick bed. 3: clast fallen from a thick bed the foot of the Grand Panel. 4: sand collected from the wall under the left group of the Triptych Panel. 5: sand collected on the right wall, opposite the Grand Panel.

\subsubsection{X-ray diffraction}

The residue after hydrochloric acid digestion of the massive limestone sample was analyzed by X-ray diffraction using a silicon calibrated Panalytical diffractometer with a Bragg-Brentano (theta-theta)configuration. Data acquisition times of 30 min allowed an angle range of 8-80 with a resolution of 0.02 . The diffraction spectra were analyzed using EVA application software coupled with the JCPDS-ICDD database. The mineral species were identified by their respective combinations of two or three characteristic peaks.

\subsubsection{X-ray Fluorescence in energy dispersive spectrometry}

Thin sections were prepared to register EDS-XRF spectra and mapping, using a SEIKO SEA 6000VX system working from 15 to $50 \mathrm{kV}$ (Rhodium source). The detector is SDD with a $50 \mathrm{~mm}^{2}$ active surface and 155 $\mathrm{eV}$ resolution. The scanned areas were $2516.65 \mathrm{~mm}^{2}$ (thin section) and $22.411 .4 \mathrm{~mm}^{2}$ (sediment $11 \mathrm{inf}$ ), with 50 microns/pixel and a collimator of 200 microns.

Light elements were detected with $15 \mathrm{kV}$ accelerating voltage with no filter, and $50 \mathrm{kV}$ was used with a $\mathrm{Pb}$ Map filter for heavy elements. Acquisition time was $100 \mathrm{~ms} /$ pixel. Spectra were extracted from the maps to quantify and provide the $\mathrm{Ca} / \mathrm{Fe}$ ratio.

\subsubsection{Raman Spectrometry}

One aggregate from a sand sample and the residue of the hydrochloritic digestion of a limestone fragment sample were analyzed with a confocal Raman microspectrometer SENTERRA (Bruker Optics, Ettlingen, Germany) equipped with both $532 \mathrm{~nm}$ and $785 \mathrm{~nm}$ exciting lines. Spectra were automatically compared with RRUFF database (Lafuente et al., 2015) 


\section{The properties of the rock support}

\subsection{Lithology}

Two lithologies can be distinguished in the cave:

- The base of walls is composed of beds with a decimetric thickness forming an irregular, stepped profile. Three sub-facies have been distinguished: the lowest beds are highly bioturbated, the next overlying ones are organized in large oblique folds several meters long, and the highest ones correspond to tempestite formations (Fig. 5). Erosion caused large rock volumes to collapse from these beds, creating obstructions in the path (Fig. 6). Outside the cave, these limestones are covered with slope colluviums.

- The beds composing the higher parts of the walls and the ceiling have a metric thickness. The speleogenesis of the cave carved out wide and regular, sub-vertical or overhanging surfaces, which most often correspond to the interface between two beds (Fig. 6). On the valley slope, the outcropping of these levels forms a rock bar with a maximum height of $3 \mathrm{~m}$ (Fig. 7), into which the cave porch opens.

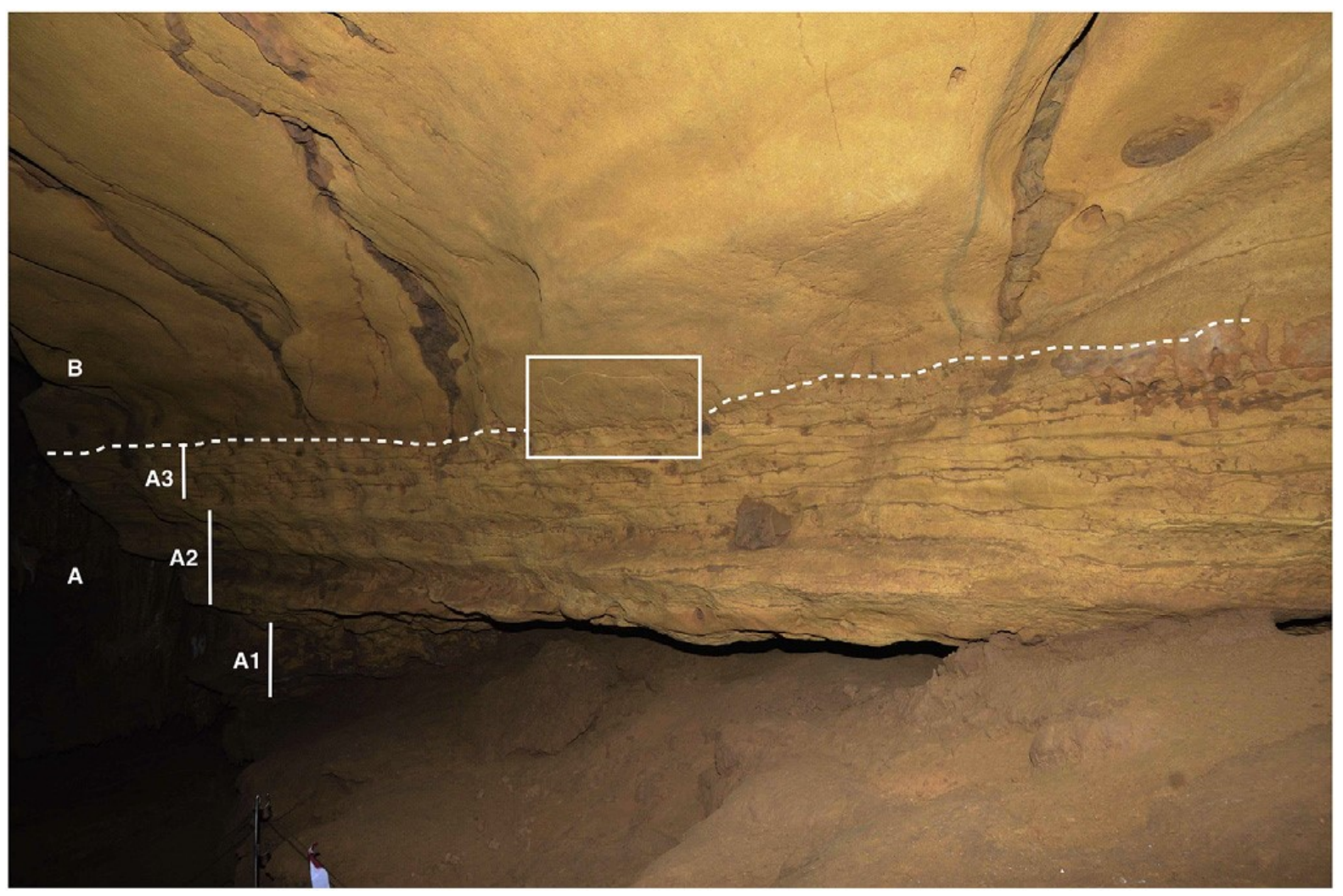

Fig. 5. Upper Campanian limestone facies visible on the cave walls. A: beds with decimetric thickness; A1: highly bioturbated beds; A2: large oblique folds; A3: tempestite formations. B: beds with metric thickness. In the square, the Isolated Mammoth (4D2-23) on the lefthand side of the Panel of the Facing Animals (photo S. Konik, PCR Cussac). 


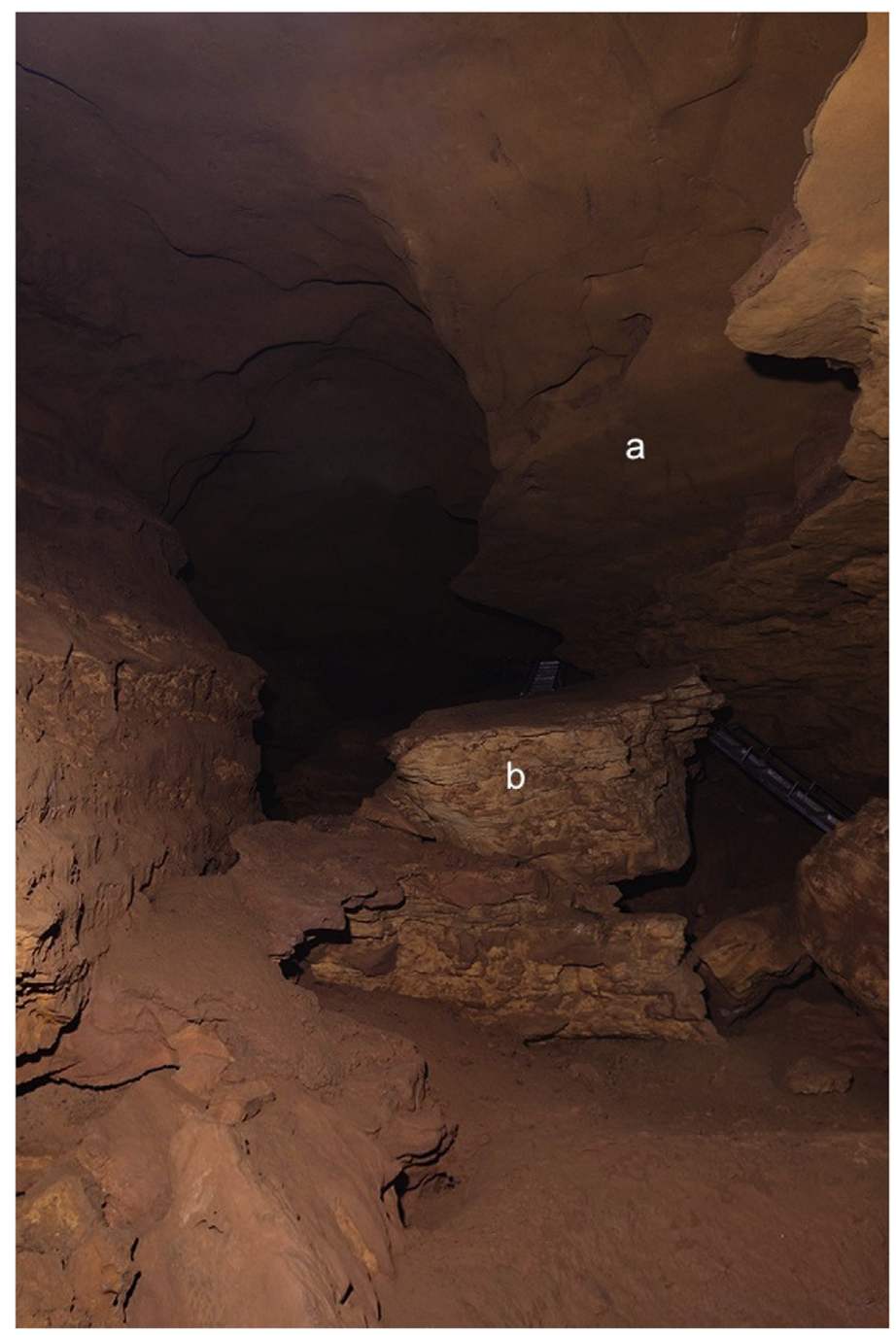

Fig. 6. Cussac Cave, Downstream Branch (photo O. Got, Universite de Bordeaux). The high part of the walls and the ceiling are composed of thick beds, resulting in large overhanging areas (a: Panel of the Discovery) or sub-horizontal surfaces. The lower part of the walls is composed of thinner beds, resulting in an irregular profile and the collapse of large rock volumes, such as this one which enabled Paleolithic people to reach the engraved surface (b).

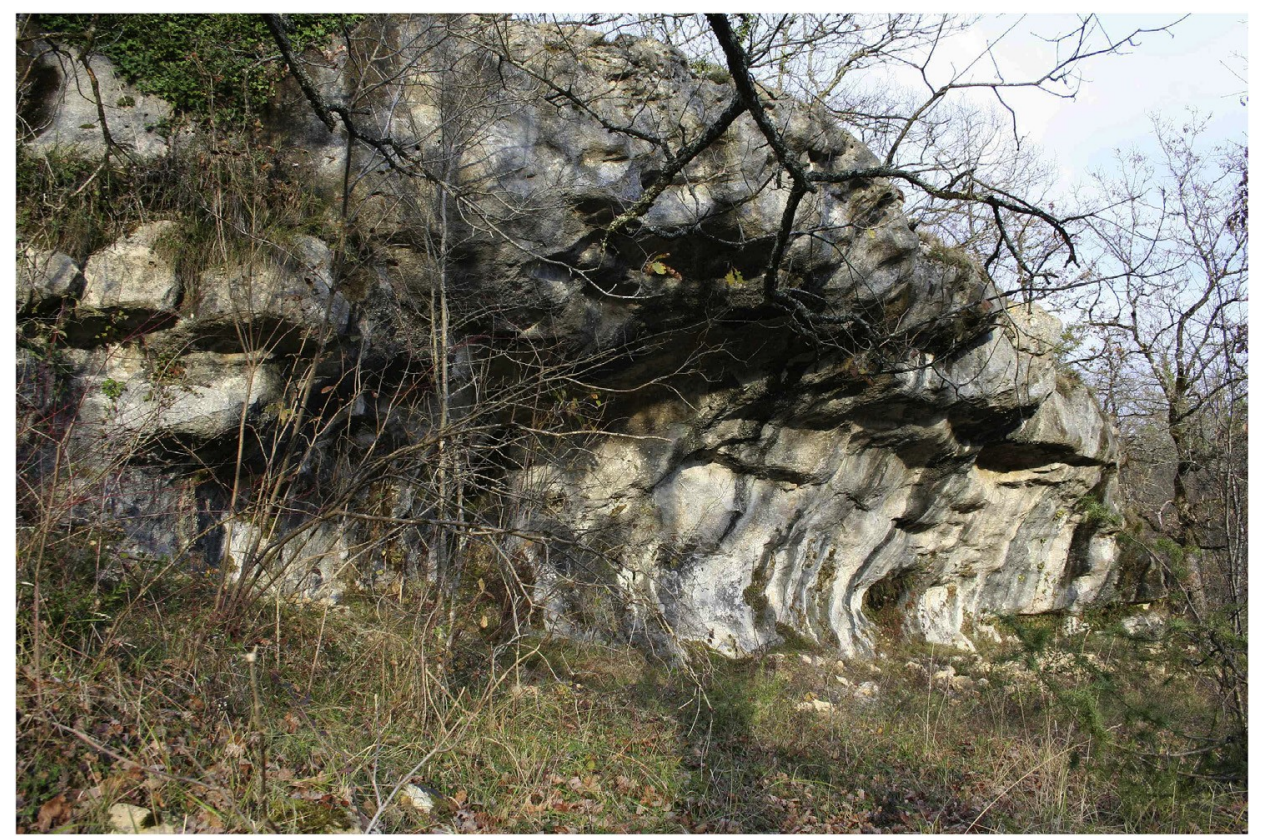

Fig. 7. Overhang composed of Upper Campanian limestone beds of metric thicknesses (photo B. Kervazo, PCR Cussac). In Cussac Cave, these beds form the upper part of the walls and ceilings. 


\subsection{Wall alterations}

The rock is composed of a sandy, yellow to red limestone with a grainstone texture. Its constituent elements - allochems (pellets, lamellibranchiata, echinoderms, bryozoan, foraminifera) and detrital grains (gravels, quartz and feldspar) - are cemented by sparite and microsparite. In the thick beds, these elements are a bit larger (coarse sands) and the porosity is qualitatively greater than in the smaller, layered beds (Fig. 8). Goethite, identified by XRD and Raman spectroscopy (Fig. 9), impregnates some micritic grains and sparitic cement in both facies (Fig. 8C and D). The proportion of residual materials after $\mathrm{HCl}$ digestion is around $8 \%$.
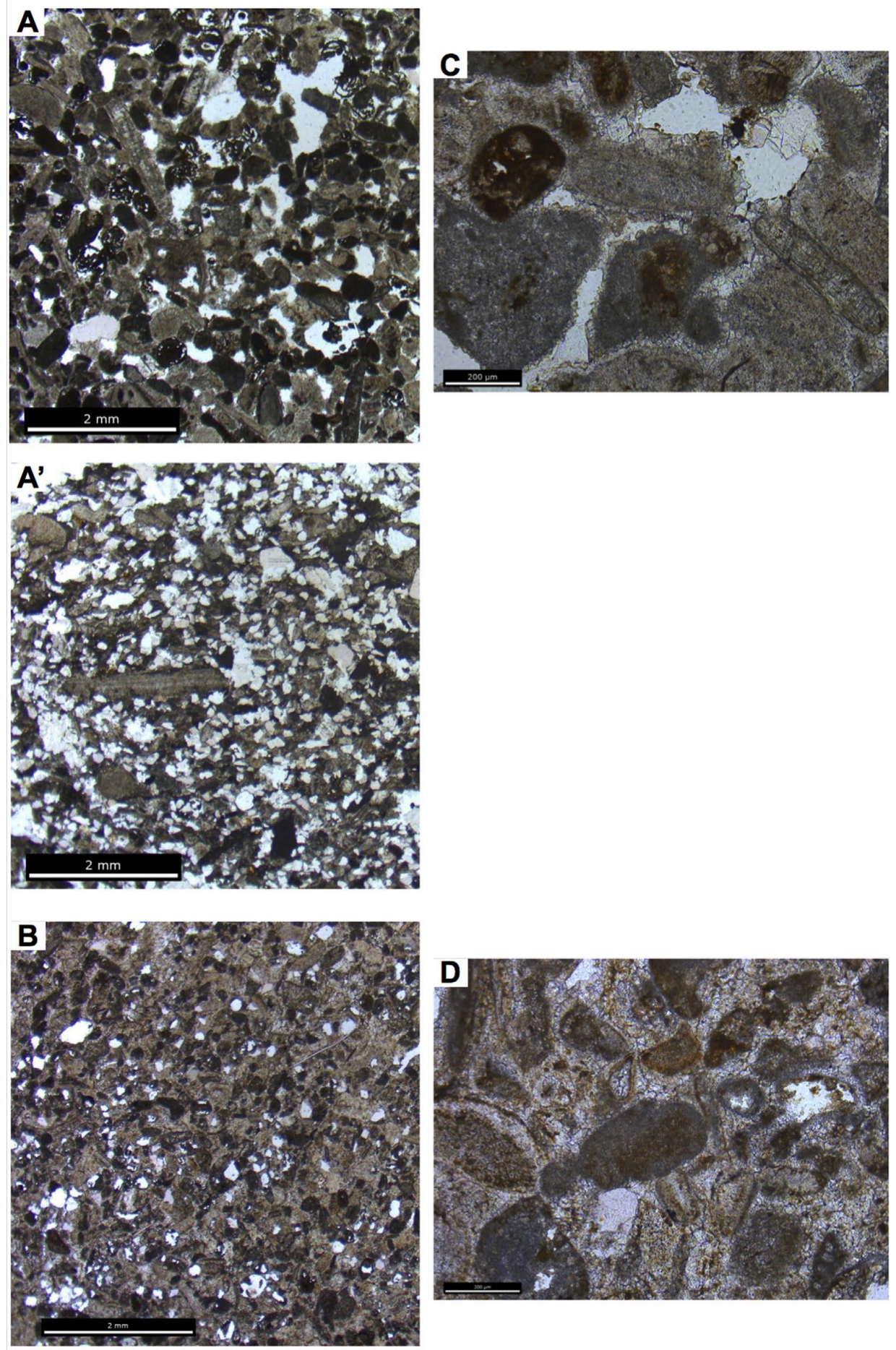

Fig. 8. Petrography of the karstified Upper Campanian levels (photos M. Ballade). A and A': limestone constituting the thick beds (upper part of the walls and ceiling of the cave) - PPL. It is composed of calcitic and quartzose sands cemented by sparite and microsparite crystals. It includes thin layers with coarser sands, rich in quartz (A0). B: limestone constituting the lower part of the walls. It is less coarse (silts) and has a lower porosity - PPL. C et D: Goethite impregnates micritic grains in both facies - PPL. 


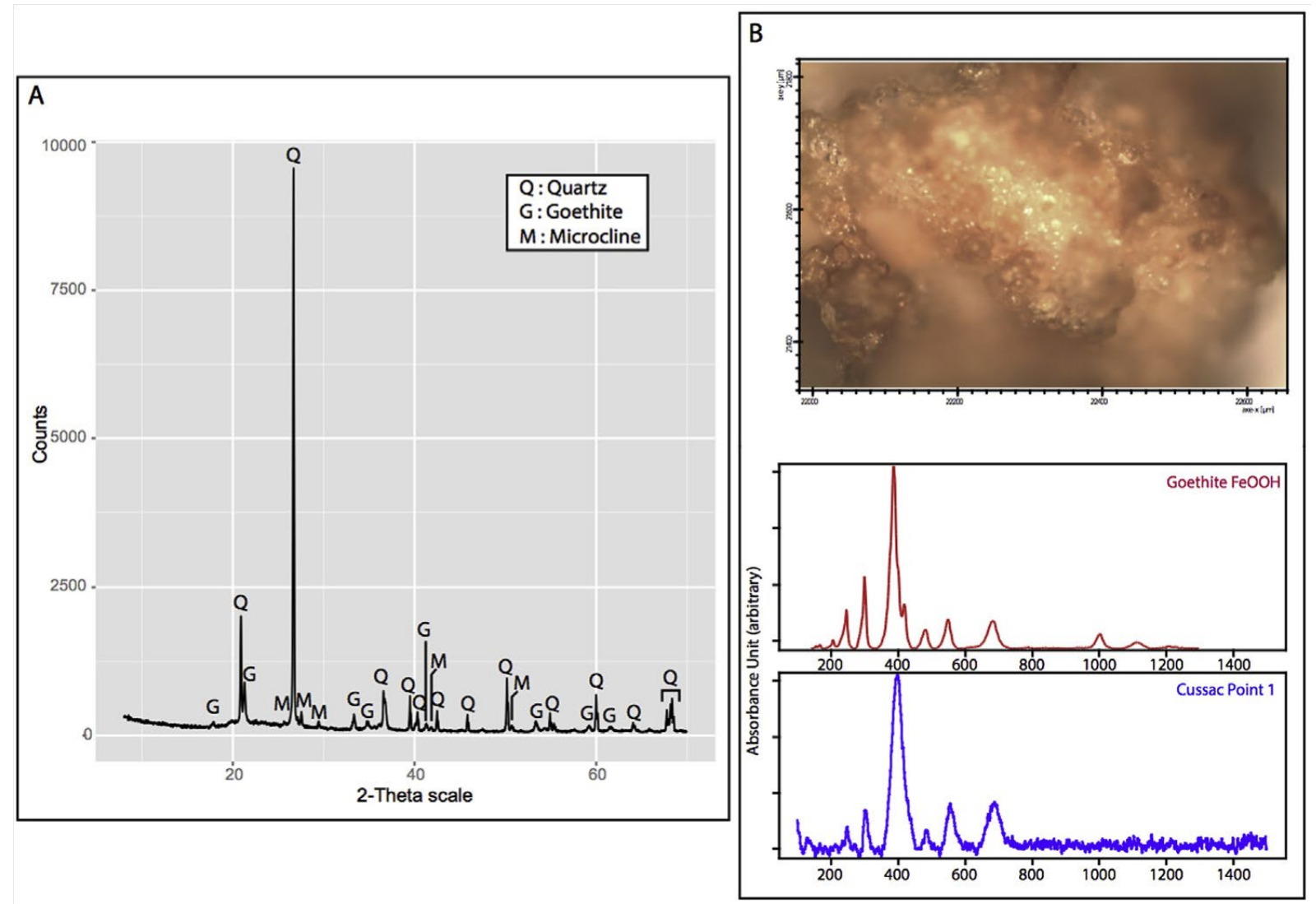

Fig. 9. Mineralogical analysis of the insoluble limestone residue forming the thick beds of the cave: presence of quartz, goethite and feldspars. A: X-ray diffraction. B. Raman spectroscopy.

Thin section analysis of rock clast detached from the thick beds shows that the face corresponding to the wall surface was subject to a partial dissolution, two to $3 \mathrm{~mm}$ thick (Fig. 10). This mainly affects the cement, as well as some of the allochems.

An XRF analysis of the variation in iron proportion between the altered superficial surface and the nonaltered rock shows a relative enrichment linked to the calcite dissolution and the goethite concentration (Fig. 11). This alteration contributes to an increased porosity, making the rock softer in the affected zone and is probably responsible for the orange-ochre coloration of the wall surfaces.

This dissolution process is also responsible for the release of calcitic grains and the insoluble minerals (quartz, feldspars and goethite) (Fig. 12) that accumulate by gravity on the ground or on wall protrusions (Fig. 13). This phenomenon was observed in twenty sectors in the Downstream Branch. The first tenuous signs of disaggregation were found at $11 \mathrm{~m}$ from the current cave entrance and become increasingly numerous toward the end of the cavity. The process was particularly active in the deep part: the number of sand accumulations increases in the $75 \mathrm{~m}$ preceding the Grand Panel, where they become denser and more continuous (Fig. 2).

A study of the lithological context indicates that this process operated mainly on the thick limestone beds, on which the majority of the engraved figures are located. 


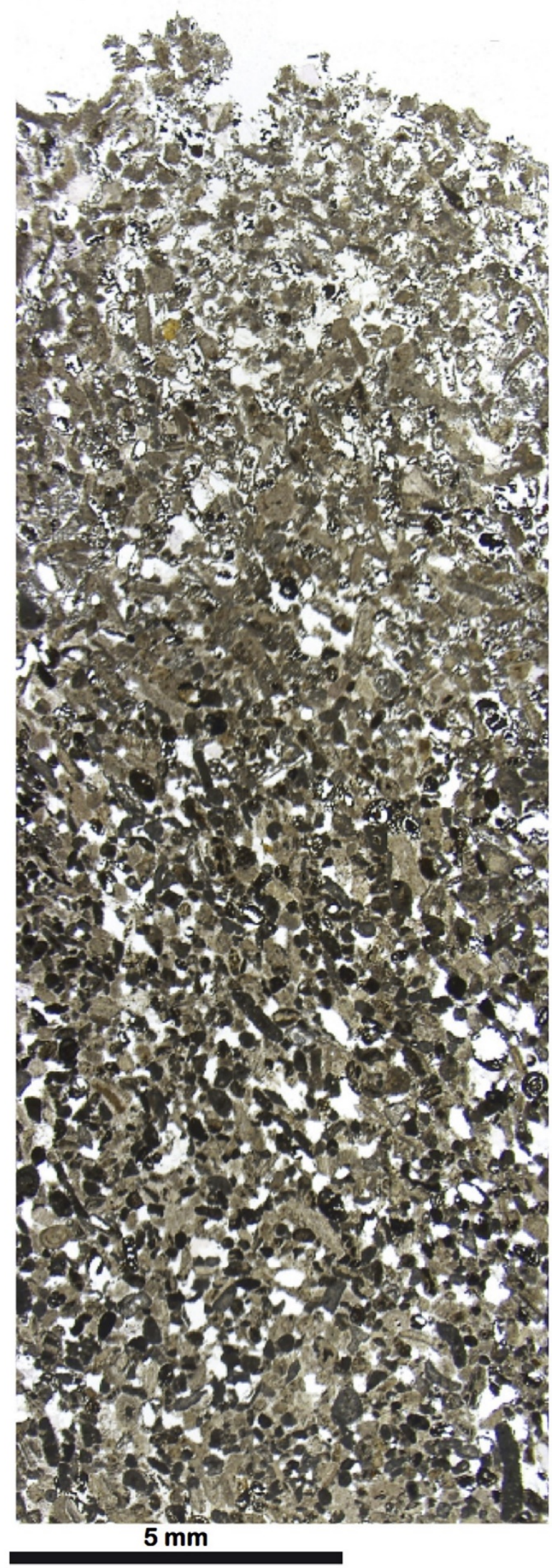

Fig. 10. Microphotography of a rock clast fallen from the thick bed at the foot of the Grand Panel. The face corresponding to the wall surface is at the top. The porosity, linked to the dissolution of the calcitic cement, is higher in this zone, through a few millimeters of thickness (PPL, photo M. Ballade). 




\begin{tabular}{|c|c|c|c|}
\hline & $\% \mathrm{Fe}$ & $\% \mathrm{Ca}$ & $\mathrm{Fe} / \mathrm{Ca}$ \\
\hline Zone 1 & 3.81 & 47.22 & 0.08 \\
\hline Zone 2 & 2.91 & 56.88 & 0.05 \\
\hline
\end{tabular}

Fig. 11. XRF analysis of the fallen rock clast at foot of the Grand Panel (thick polished section). Zone 1 is located in the altered rock or patina. Zone 2 is from the non-altered rock. Mean values (out of 4 acquisitions) of chemical composition for Fe and Ca, are given in relative percentage.

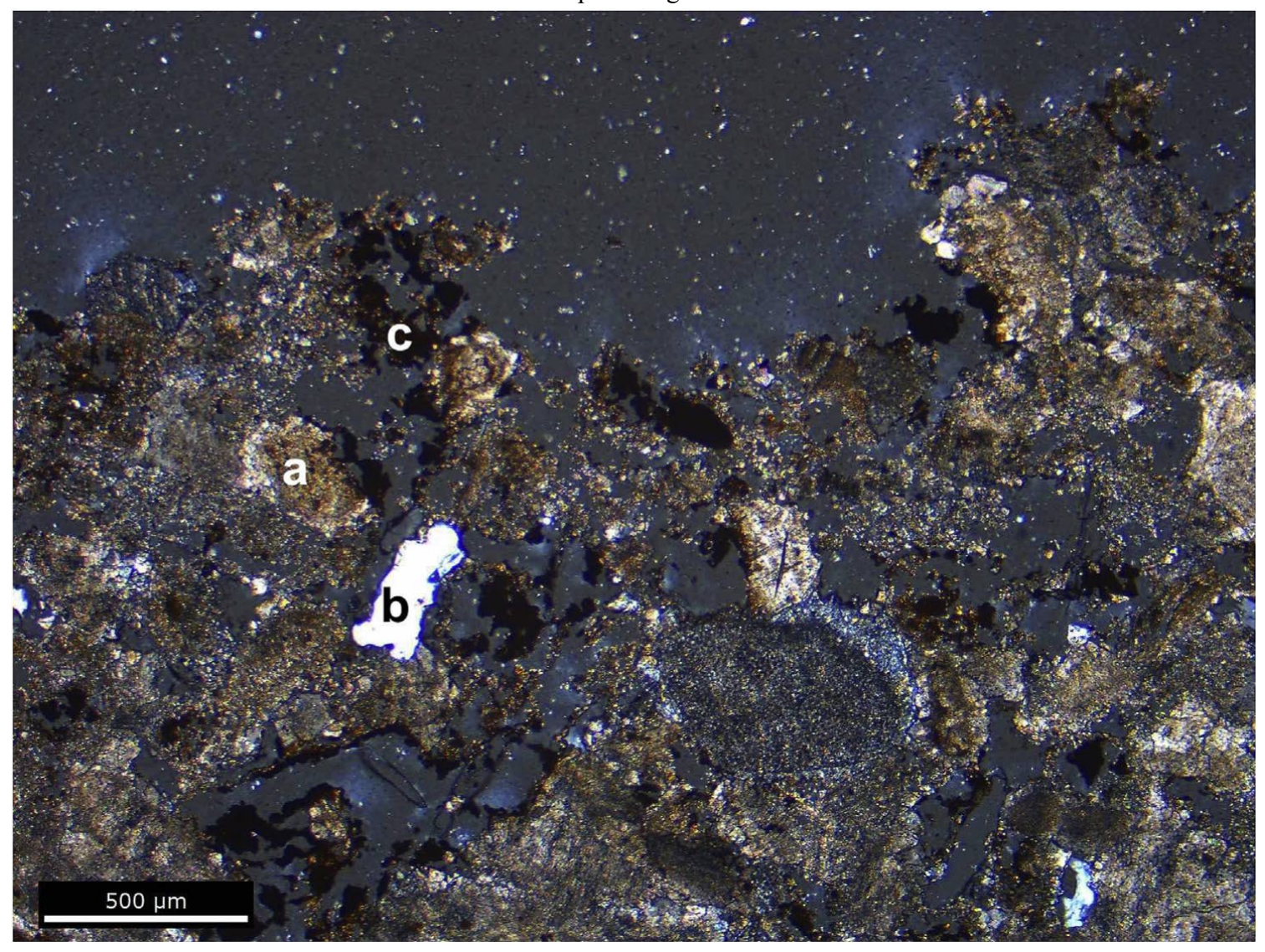

Fig. 12. Disaggregation due to the dissolution of the sparitic cement. The micritic grains (a), quartz (b), and goethite (c) are released and then accumulate on the cave floor (XPL, photo M. Ballade). 


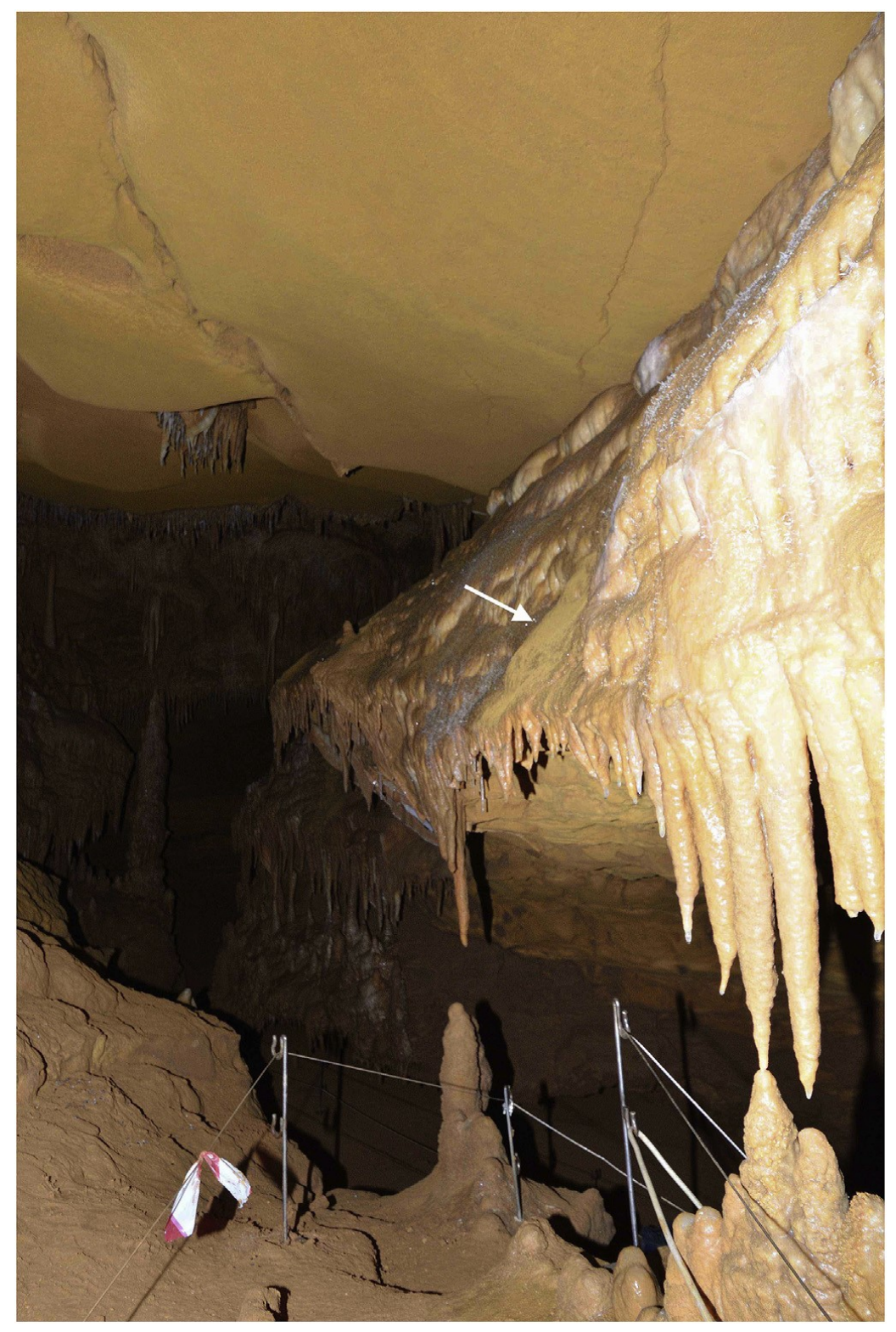

Fig. 13. Sand accumulation resulting from the alteration of the thick beds forming the ceiling near the Triptych Panel (photo S. Konik, PCR Cussac).

\section{Archaeological implications}

\subsection{Lithology and the parietal art distribution}

The large, relatively flat and sub-horizontal surfaces formed by the collapse of thick beds along stratification joints (middle zone) were preferentially decorated by the Paleolithic artists. They permitted the realization of large figures and panels, such as the bison (over $3.5 \mathrm{~m}$ long) on the Grand Panel (5G2-38). The figures and the motifs located on the lower part of the walls are much smaller as they were constrained by the thinness of the limestone beds. Only two panels are entirely engraved on the thin-bedded facies, four are straddled between the thick bands and thinner bedded bands, and the 24 others are located only on the thick bands.

\subsection{Rock surface properties and technical choices}

Several properties of the wall surface resulting from its alteration can explain the artists' choice to engrave rather than paint, as well as the types of engravings realized: 
- the low cohesion of the rock surface, due to the dissolution of the calcite that cements the limestone grains, enabled the easy realization of deep and wide incisions using hard or soft tools. It also permitted the creation of "Egyptian" relief by scraping one of the edges of the incision to soften the shadow and thus creates a modeled effect (Fig. 14). The softness and friability of the support also permitted the realization of fingertracings, resembling the older, contemporary or more recent ones in other caves, such as Chauvet-Pont d'Arc (Clottes dir., 2001), Cosquer (Clottes et al., 2005), Gargas and Rouffignac (Plassard, 1999). In contrast to Cussac, however, the surfaces engraved by finger-tracing in these caves are composed of soft limestone or limestone covered with mondmilch.

- - the color contrast between the superficial altered wall surface that corresponds to the patina and the lighter, underlying zone exposed in the bottom of the incisions, combined with the large size of the representations, contributes to the visibility of the figures and their spectacular appearance.

In Cussac Cave, the properties of the support surface thus offered technical opportunities that the engravers knew how to use, and they adapted their technical choices to the specific properties e especially texture e of the surface to be engraved.

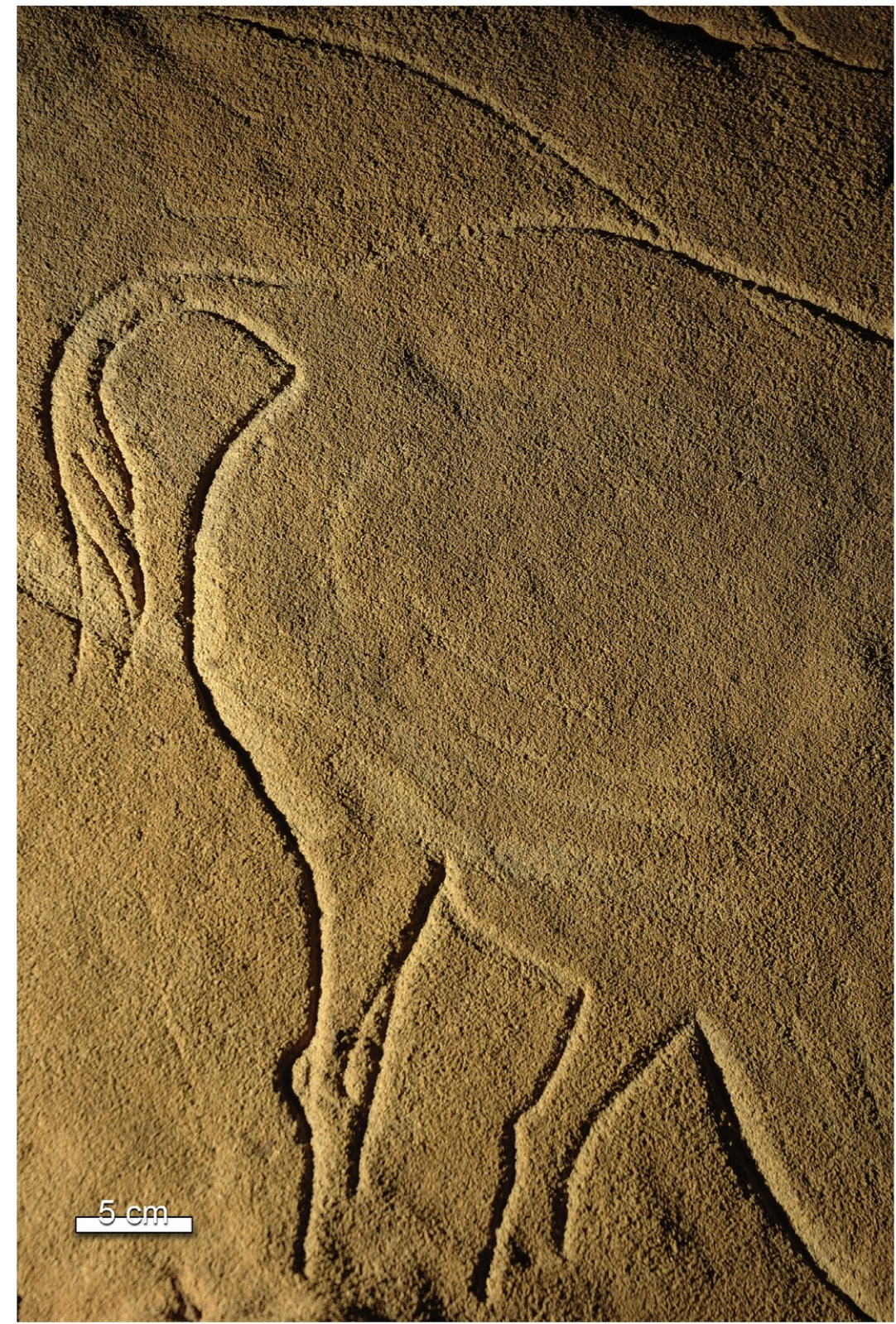

Fig. 14. Panel of the Discovery, example of an "Egyptian" engraving of a bison hindquarter (photo V. Feruglio, PCR Cussac). 
The study of the Triptych Panel revealed that the depth, width and precision of the engraved lines are closely linked to the rock surface properties, determined by the intensity of the alteration undergone by the wall before it was decorated. This alteration is manifest in differences in the rugosity of the rock surface, which vary depending on the wall morphology:

- - the less protruding and convex parts have a low to medium rugosity that corresponds to the less altered zones. Here the engraved lines are narrow (in the millimeter range) and have clean edges;

- - on the more protruding parts, the alteration is greater and the rugosity is higher, caused by the detachment of limestone grains. These surfaces are visually distinct due to their lighter color. Here, the engraved lines are wider and less visible, such as those of the back legs of the bison (Fig. 14).

This relationship between the rugosity of the rock surface and the morphology of the walls is found throughout the Downstream Branch and could be related to the condensation/corrosion process (Dublyansky and Dublyansky, 2000), which is more active on convex surfaces than on concave ones. Its influence on the morphology of the engraved lines was also observed on the Panel of the Isolated Mammoth (4D3), whose lines are more incisive and narrower on the concave surfaces. By influencing the morphology of the engraved lines, whose variations can also result from changes in the pressure and/or inflexion of the engravers' movements, the properties of the rock surface contributed to the visual appearance of the engravings.

\subsection{Rock surface properties and the presence of other intentional and unintentional marks}

Due to the nature of the limestone at Cussac and its degree of alteration, rare in decorated caves, marks and lines that we would normally expect to see on plastic surfaces such as clay or mondmilch were realized by the artists and remain visible. These marks and lines are of two types: intentional, such as finger-tracings, or unintentional, such as the marks created by the resting hand of an engraver on the periphery of the figures of the Panel of the Discovery 2D1 (Aujoulat et al., 2013, Fig. 14). Curiously, we have not observed any rubbing of the surface, which could have created "colored" zones to fill-in the figures or to represent fur, shadowing or modeling. Though the Gravettian artists did not take advantage of this very specific support property, Magdalenian artists did in the caves of Les Trois-Freres (Ari ege, France) ( Begou en et al., 2014€), Altxerri (Guipuzcoa, Spain) (Altuna and Apellaniz, 1976) and even Massat (Ariege, France) ( Barriere, 1990 ).

\section{Conclusions and perspectives}

This study of the rock supports in Cussac Cave and their alterations have enabled us to better understand the conditions in which the parietal art works were realized, as well as the technical choices made by the Gravettian artists. The results show the influence of the lithological properties and surface conditions of the supports on different aspects of the graphic expressions. It appears that monumental engraving was facilitated by the large surfaces exposed by the karstogenesis and the specific nature of the thick limestone bed, whose friable surface results from the dissolution of the rock cement through a few millimeters in thickness. The choice to engrave in this manner on this surface contributes to the exceptional nature of the art in Cussac Cave.

Due to fragility of the patina on several decorated panels, the stigmata created by subtle differences in the movements of the artists can be observed, such as changes in tool pressure, along with diverse marks unintentionally made during the realization of the depictions (Panel of the Discovery), such as light rubbing across the wall or indentations made by resting hands.

The alterations responsible for the state of the wall when the engravings were made sometimes continued after the graphic depictions were realized. This is the case of the right part of the Triptych Panel near the depiction of a "goose" with a broken neck 4G1-6 and the base of the horns or ears of the animal head 4G1-8 (Fig. 3), where the falling of grains freed by the cement dissolution resulted in a loss of material and the erosion of the engraved 
lines, which thus appear shallower. On the other decorated panels, it is sometimes difficult to untangle the chronological order of engravings and alterations. The potential influence of the engravings on the taphonomic evolution of the walls is also difficult to evaluate and will be further explored in future research.

Studies of the rock support are often integrated into research on parietal art, but never as a constituent element of the artistic procedure or as a contributing factor in its final rendering. Thanks to its very recent discovery, ensuring the preservation of multiple lines of evidence, Cussac Cave offers this possibility and enables us to more precisely interrogate the work of the artists. This art now appears much more complex and complete, integrating parameters far beyond the spontaneous artistic acts that we too often imagine.

\section{Acknowledgments}

We thank the French Ministry of Culture and Communication, MCC (DRAC-SRA Aquitaine), Bordeaux, the University of BordeauxPACEA, Magen O'Farrell for editing and translation. We are grateful to Eric Lebraud (ICMCB e UPR9048 CNRS) who performed the XRD acquisition. This work is mainly supported by French MCC (DRACSRA Aquitaine) and in part by others laboratories and French institutions of the authors and by the LabEx LaScArBx (label of excellence Archaeological Sciences Bordeaux) according to the general program supported by the ANR (Agence Nationale de la Recherche) e n-ANR-10-LABX-52.

\section{References}

Altuna, J., Apellaniz, J.M., 1976. Las figuras rupestres paleolíticas de la Cueva de Altxerri (Guipuzcoa). Munibe $28(1 \mathrm{e} 3), 3 \mathrm{e} 242$.

Aujoulat, N., 2004. Lascaux : Le geste, l'espace et le temps. Coll. Arts rupestres. Editions du Seuil, Paris, 273 p.

Aujoulat, N., 2005. La grotte de Cussac. Le Buisson-de-Cadouin (Dordogne). Rapport. Potentiel archeologique. Observations e reflexions e perspectives. Perigueux : ministere de la Culture et de la Communication. Centre national de P rehistoire, departement d'art parietal, 57 p., [textes de C. Ferrier, B. Kervazo, J.-M. Geneste, D. Henry-Gambier, P. Courtaud et H. Duday].

Aujoulat, N., Geneste, J.-M., Archambeau, Ch, Delluc, M., 2000. La grotte ornee de Cussac. Spel eo-Dordogne, 156, 4e trim. 2000 [special grotte de Cussac], pp. 25e27.

Aujoulat, N., Geneste, J.-M., Archambeau, Ch, Delluc, M., Duday, H., Gambier, D., 2001a. La grotte ornee de Cussac (Dordogne). Observations liminaires. PALE O 13, 9e18 decembre 2001.

Aujoulat, N., Geneste, J.-M., Archambeau, Ch, Barraud, D., Delluc, M., Duday, H., Gambier, D., 2001b. La grotte ornee de Cussac [The Decorated Cave of Cussac]. INORA 30, 3 e9.

Aujoulat, N., Geneste, J.-M., Archambeau, Ch, Barraud, D., Delluc, M., Duday, H., Henry-Gambier, D., 2002. La grotte ornee de Cussac e Le Buisson-de-Cadouin (Dordogne) : premieres observations. Bulletin de la Societ e p rehistorique française 99 (1), 129e137.

Aujoulat, N., Geneste, J.-M., Archambeau, Ch, Delluc, M., Duday, H., Gambier, D., 2004. La grotte ornee de Cussac Le Buisson-de-Cadouin (Dordogne). In: Lejeune (Dir), M. (Ed.), L'Art parietal paleolithique dans son contexte naturel, actes du Colloque 8.2, Congres de l'UISPP, Liege, 2e8 septembre 2001, Liege, pp. 45e53. ERAUL 107.

Aujoulat, N., Feruglio, V., Fourment, N., Henry-Gambier, D., Jaubert, J., 2013. Le sanctuaire gravettien de Cussac (Le Buisson_de_Cadouin, Dordogne, France) : premiers résultats Projet Collectif de Recherche, The Gravettian Sanctuary of Cussac (Le Buisson-de-Cadouin Dordogne, France): first Results of a Team Research Project. International Newsletter of Rock Art Research INORA 65, 7e19.

Barriere, Cl, 1990. L'art pariétal du Ker de Massat. Presses univ. Le Mirail, Toulouse, 144 p.

Begoue€n, R., Clottes, J., Feruglio, V., Pastoors, A., 2014. La Caverne des Trois-Freres, Anthologie d'un exceptionnel sanctuaire prehistorique. Somogy editions d'art et Association Louis Begoue€n, 248 p.

Brunet, J., Vouve, J., 1996. La conservation des grottes ornees. Ed du CNRS, 263 p. 
Capitan, L., Breuil, H., Peyrony, D., 1910. La Caverne de Font-de-Gaume aux Eyzies (Dordogne). imprimerie Chêne, Monaco, 271 p.

Clottes (dir), J., 2001. La grotte Chauvet, L'art des origines. Le Seuil, Paris, 224 p.

Clottes, J., Courtin, J., Vanrell, L., 2005. Cosquer redecouvert. Editions du Seuil, Paris, 255 p.

Delluc, M., 2000. La grotte de Cussac. Commune du Buisson-de-Cadouin (24). Speleo-Dordogne 156, $4^{e}$ trimestre 2000 [special grotte de Cussac], pp. 19e24.

Dublyansky, V.N., Dublyansky, Y.V., 2000. The role of condensation in karst hydrogeology and speleogenesis. In: Klimchouk, A., Ford, D.C., Palmer, A., Dreybrodt, W. (Eds.), Speleogenesis: Evolution of Karst Aquifers. National Speleological Society, pp. 100e111.

Ferrier, C., Debard, E., Kervazo, B., Aujoulat, N., Baffier, D., Feruglio, V., Fritz, C., Gely, B., Geneste, J.-M., Konik, S., Lacanette, D., Lastennet, R., Maksud, F., Malaurent, Ph, Plassard, F., Tosello, G., 2012. Approche taphonomique des parois des grottes ornees. In: L'art prehistorique dans le monde, Actes du Congres IFRAO, Tarascon-sur-Ariege, septembre 2010, Symposium 6 " Datation et taphonomie de l'art pleistocene ", J. Clottes dir, p. 192 (livre) et 1071 (CD).

Fourment, N., Barraud, D., Kazmierczak, M., Rieu, A., 2012. La grotte de Cussac (Le Buisson-de-Cadouin, Dordogne, France) : applications des principes de conservation preventive au cas d'une decouverte recente. In: Clottes dir, J. (Ed.), L'art pleistocene dans le monde/Pleistocene art of the world/Arte pleistoceno en el mundo, Actes du Congres IFRAO, Tarascon-sur-Ariege, septembre 2010. Prehistoire, Art et societes, pp. 343e354. LXV-LXVI 2010-11, 64e65 et CD-Rom EUR20.

Henry-Gambier, D., Courtaud, D., Duday, H., Dutailly, B., Villotte, S., Deguilloux, M.F., Pemonge, M.-H., Aujoulat, N., Delluc, M., Fourment, N., Jaubert J., 2013. Grotte de Cussac (Le Buisson-de-Cadouin) : un exemple de comportement original pour le Gravettien. In: P. Courtaud, H. Duday et S. Rottier (dir), Les comportements funéraires dans la Préhistoire : transition, rupture ou continuité ?, In: J. Jaubert, N. Fourment, P. Depaepe (Eds.), Transitions, ruptures et continuit e en Prehistoire, Actes du XXVIIe congrès préhistorique de France, Bordeaux - Les Eyzies 31 mai-5 juin 2010, Paris, Société préhistorique française 1, 169 e182.

Jaubert, J., 2015. Une invitation a Jirí Svoboda pour jumeler le complexe pavlovien de Moravie et la grotte ornee et funeraire d'a^ge Gravettien de Cussac. In: Sazelova, S., Novak, M., Mizerova, A. (Eds.), Forgotten Times Ans Spaces. New Perspectives in Paleoanthropological, Paleoethnological and Archaeological Studies. Muni Press, Institute of Archaeology of the Czech Academy of Sciences, Brno, V.V.I. \& Masaryk University, Brno, pp. 214e228.

Jaubert, J., Aujoulat, N., Courtaud, P., Deguilloux, M.-F., Delluc, M., Denis, A., Duday, H., Dutailly, B., Ferrier, C., Feruglio, V., Fourment, N., Geneste, J.-M., Genty, D., Goutas, N., Henry-Gambier, D., Kervazo, B., Klaric, L., Lastennet, R., Leve^que, F., Malaurent, P., Mallye, J.-B., Mora, P., Pemonge, M.-H., Peyraube, N., Peyroux, M., Plisson, H., Portais, J.-C., Valladas, H., Vergnieux, R., Villotte, S., 2012. Le projet collectif de recherche "Grotte de Cussac » (Dordogne, France) : etude d'une cavite ornee a vestiges humains du Gravettien. In: L'art pleistocene dans le monde/Pleistocene art of the world/Arte pleistoceno en el mundo. Actes du Congres IFRAO, Tarascon-sur-Ariege, septembre 2010 e Symposium « Art pleistocene en Europe », n special de Prehistoire, Art et Societes, Bulletin de la Societe Prehistorique Ariege-Pyrenees, LXV-LXVI, 2010-2011, Livre synthese, pp. 62e63. CD : 325-342.

Jaubert, J., Genty, D., Valladas, H., Courtaud, P., Ferrier, C., Feruglio, V., Fourment, N., Konik, S., Villotte, S., Bourdier, C., Costamagno, S., Delluc, M., Goutas, N., Katnecker, E., Klaric, L., Langlais, M., Ledoux, L., Maksud, F., O'Farrell, M., Mallye, J.-B., Pierre, M., Pons-Branchu, E., Regnier, E., Thery-Parisot, I., 2016. The chronology of human and animal presence in the decorated and sepulchral cave of Cussac (France) XVII World UISPP Congress, Session A11a, the Chronology of Palaeolithic Cave Art: New Data, New Debates, 1e7 September, Burgos. Quaternary International 432B, 5e24.

Karnay, G., Aujoulat, N., Konik, S., Mauroux, B., Pluchery, E., Turq, A., 1999. Notice explicative de la feuille Le Bugue. Carte geologique de la France a 1/50000, Editions du BRGM, 86 p.

Kervazo, B., Feruglio, V., Baffier, D., Debard, E., Ferrier, C., Perroux, A.-S., Aujoulat, N., Delannoy, J.-J., Perrette, Y., 2010. Parois et art parietal : approche taphonomique. L'exemple de la grotte Chauvet (Pont d'Arc). 
In: Mise en commun des approches en taphonomie, actes du workshop n16, XVe congres international de l'UISPP, Lisbonne, septembre 2006, pp. 43e52. Paleo supplement 3.

Lafuente, B., Downs, R.T., Yang, H., Stone, N., 2015. The power of databases: the RRUFF project. In: Armbruster, T., Danisi, R.M. (Eds.), Highlights in Mineralogical Crystallography. W. De Gruyter, Berlin, Germany, pp. 1e30.

Lemozi, A., 1929. La grotte temple du Pech-Merle, un nouveau sanctuaire prehistorique. Picard, Paris.

Lorblanchet, M., 1992. Finger markings in Pech-Merle and their place in prehistoric art. In: Lorblanchet dir, M. (Ed.), Rock Art in the Old World, AURA Congress, Darwin 1988, New Delhi.

Lorblanchet, M., 1993. Le support. In: GRAPP, L'art parietal paleolithique, techniques et methodes d'etude. du CTHS, Paris, pp. 69e80.

Lorblanchet, M., Delpech, F., Renault, Ph, Andrieux, C., 1973. La grotte de SainteEulalie a Espagnac. Gallia Prehistoire 16 (1), 3e62.

Lorblanchet, M., Delpech, F., Leroi-Gourhan, A., Renault, Ph, Brunet, J., Vidal, P., 1979. Pech-Merle : recherches recentes. Congres prehist. Fr., 21, Quercy, 1979, 68 p.

Platel, J.-P., 1989. Le Cretace superieur de la plate-forme septentrionale du bassin d'Aquitaine. Stratigraphie et evolution geodynamique. These Doctorat d'Etat es Sciences. Universite de Bordeaux III. Documents BRGM 164,573 p. avec atlas.

Platel, J.-P., 1996. Stratigraphie, sedimentologie et evolution geodynamique de la plate-forme carbonatee du Creta ce su perieur du Nord du bassin d'Aquitaine. Geologie de la France 4, 33 e58.

Plassard, J., 1999. Rouffignac, le sanctuaire des mammouths. Editions du Seuil, Paris, 96 p.

Renault, P., 1987. Pheno menes karstiques. In: Geologie de la Prehistoire : methodes, techniques, applications, pp. 169e196. GEOPRE, J.-C. Miskovski dir.

Renault, P., 1989. Etude micromorphologique des parois decorees. In: L'art parietal paleolithique, actes des colloques de la Direction du Patrimoine, Perigueux e Le Thot, novembre 1984, pp. 203e205. 